\title{
Світлана Мороз
}

кандидат наук з державного управління, старший науковий співробітник навчальнонауково-виробничого центру, Національний університет цивільного захисту; Харків,

України

E-mail:ra_ekma@yahoo.com

\section{Інта Бука}

магістр ділового адміністрування, проректор з міжнародної діяльності, Балтійська Міжнародна Академія (Латвія)

E-mail: inta.buka@bsa.edu.lv

\section{Володимир Мороз}

доктор наук з державного управління, професор, кафедра педагогіки і психології управління соціальними системами, Національний технічний університет "Харківський політехнічний інститут"; Харків, Україна

E-mail:moroz32@rambler.ru

\section{Станіслав Бука}

доктор економічних наук, професор, голова сенату, Балтійська Міжнародна Академія

(Латвія)

E-mail: info@bsa.edu.lv

\section{ФАКТОРИ ВИБОРУ МІСЦЯ ЗДОБУТТЯ ВИЩОЇ ОСВІТИ ЯК ОБ'ЄКТ ПУБЛІЧНОГО УПРАВЛІННЯ ЗАБЕЗПЕЧЕННЯМ ЇЇ ЯКОСТІ (ЗА РЕЗУЛЬТАТАМИ ОПИТУВАННЯ СТУДЕНТІВ УКРАЇНСЬКИХ ЗАКЛАДІВ ВИЩОЇ ОСВІТИ)}

Анотація: в публікації висвітлено результати опитування студентів щодо сили прояву окремих детермінант якості вищої освіти. За результатами аналізу відповідей респондентів було встановлено факт домінування тих складових змісту феномену якості вищої освіти, які пов'язані з формуванням конкурентних переваг фахівця та його здатністю до отримання більшого рівня заробітної плати. Найменша за силою прояву значущість у формуванні категоріального змісту якості вищої освіти, на думку студентів, відведена детермінантам можливості людини здійснювати особистісний розвиток та розуміти зміст подій навколо себе. Обгрунтовано напрями вдосконалення змісту та практики використання нормативно-правового механізму державного управління забезпеченням якості вищої освіти та подано пропозиції щодо зміни фокусу уваги у тлумаченні змісту відповідної категорії.

Ключові слова: вибір місця здобуття вищої освіти; опитування студентів; заклад вищої освіти; якість вищої освіти; публічне управління якістю вищої освіти; мотиви абітурієнта.

(C) Світлана Мороз, Інта бука, Володимир Мороз, Станіслав Бука, 2020 


\section{Svitlana Moroz}

candidate of Public Administration (PhD), Senior Research Officer of Training Research and Production Center, National University of Civil Protection of Ukraine; Kharkiv, Ukraine E-mail: ra_ekma@yahoo.com

\section{Inta Buka}

MBA, Vice-rector for International Cooperation, Baltic International Academy (Latvia) E-mail: inta.buka@bsa.edu.lv

\section{Volodymyr Moroz}

doctor of sciences (Public Administration), Full Professor of Pedagogy and Psychology of Social Systems Management Department of the academician I. A. Ziaziuna of The National Technical University "Kharkiv Polytechnic Institute",

E-mail:moroz32@rambler.ru

\section{Stanislav Buka}

doctor of sciences (economics), professor, head of senate academy, Baltic International Academy (Latvia)

E-mail: info@bsa.edu.lv

\section{FACTORS INFLUENCING THE CHOICE OF THE PLACE FOR OBTAINING OF HIGHER EDUCATION AS AN OBJECT OF PUBLIC MANAGEMENT ENSURING ITS QUALITY (ACCORDING TO A SURVEY OF STUDENTS OF UKRAINIAN INSTITUTIONS OF HIGHER EDUCATION)}

Abstract: the article presents the results of a survey of students regarding the strength of certain factors influencing the choice of place for obtaining higher education by applicants. The article presents the results of the analysis of power of the influence of factors such as the proximity of the Institute of Higher Education to the place of residence of the applicant; the place of positioning of the Institute of Higher Education in international University rankings, the reputation of the Institute of Higher Education in the immediate environment of the applicant; development of the infrastructure in Institute of Higher Education and the city which it is located in; traditions of Institute of Higher Education in specialists training. The article considers the relationship between the factors of choosing a place of higher education and the problem of ensuring its quality. The article contains generalizations and conclusions about possible mechanisms of influence of administrations of Institute of Higher Education and public authorities on the applicants' formation of motives regarding the choice of the place for obtaining of higher education and ways of improving mechanisms of public administration to ensure its quality.

Key words: choice of place getting of higher education; student survey; higher education institution; quality of higher education; public administration of quality of higher education; motivation of applicant. 


\section{ФАКТОРЫ ВЫБОРА МЕСТА ПОЛУЧЕНИЕ ВЫСШЕГО ОБРАЗОВАНИЯ КАК ОБЪЕКТ ПУБЛИЧНОГО УПРАВЛЕНИЯ ОБЕСПЕЧЕНИЯ ЕЕ КАЧЕСТВА (ПО РЕЗУЛЬТАТАМ ОПРОСА СТУДЕНТОВ УКРАИНСКИХ УЧРЕЖДЕНИЙ ВЫСШЕГО ОБРАЗОВАНИЯ)}

Аннотащия: в публикации освещены результаты опроса студентов по силе проявления отдельных детерминант качества высшего образования. По результатам анализа ответов респондентов был установлен факт доминирования тех составляющих содержания феномена качества высшего образования, связанные с формированием конкурентных преимуществ специалиста и его способностью к получению большего уровня заработной платы. Наименьшая по силе проявления значимость в формировании категориального содержания качества высшего образования, по мнению студентов, отведена детерминантам возможности человека осуществлять личностное развитие и понимать смысл событий вокруг себя. Обоснованы направления совершенствования содержания и практики использования нормативно-правового механизма государственного управления обеспечением качества высшего образования и представлены предложения по изменению фокуса внимания в толковании содержания соответствующей категории.

Ключевые слова: выбор места получения высшего образования; опрос студентов; учреждение высшего образования; качество высшего образования; публичное управления качеством высшего образования; мотивы абитуриента.

\section{Svitlana Moroz, Inta Buka, Volodymyr Moroz, Stanislav Buka}

An extended abstract of a paper on the subject of:

"Factors influencing the choice of the place for obtaining of higher education as an object of public management ensuring its quality (according to a survey of students of Ukrainian institutions of higher education)"

Problem setting. The constant conditions change in the market of educational services requires from the Institute of Higher Education a deeper understanding of both, the specifics of the applicants' formulation of motives regarding their choice of a that or another Institute of Higher education and (or) specialty, and the content of employers' requests regarding the quality of the labour potential of future specialists. Finding out students' opinions about the power of influence of certain factors on the choice of their place of obtaining professional knowledge is one of the tools for forming an information and analytical base for improving both, the management mechanisms of the entrance company at the University level and the mechanisms of public administration of ensuring of the higher education quality at the state level.

Recent research and publications analysis. Considering og the students' point of view on the level of results of expert analysis in not a fundamentally new way to organize scientific research. Relevant way obtains its development in works of $W$. Ansari, S. Buka, M. Green, D. Kane, A. Maxwell, S. Meier, V. Naydenova, S. Porter, S. Sagu, E. Smith, P. Umbach, M. Wallace, J. Wilson and other scientists. Among domestic scientists problematics of students' participating in providing higher education quality found its reflection in researches of 
V.M. Babayev, L.M. Gren, S.M. Dombrovska, S.A. Kalashnikova, V.I. Luhovyi, V.M. Moroz, A.V. Ozarovs`ka, L.I. Parashhenko, O.G. Romanovskiy, V.P. Sadkovyi and other researches. Despite the sufficient level of the scientific attention to the problematics of the survey of students, some of its questions are still open for the further science researches.

Paper objective. The results of the analysis of students' evaluation of the strength of of certain factors influencing the choice of place for obtaining higher education was chosen to be the object of this research.

Paper main body. In accordance with the objectives of the author's post-grant project "Assessment of the higher education quality", there was conducted a survey of 542 respondents aged 18 to 35 years from Poltava, Sumy, Kharkiv, as well as in controlled by Ukraine parts of the Donetsk and Luhansk regions. Selective interview (to clarify the content of the questionnaire and the level of its understanding by potential respondents) and a questionnaire (to get information about the subject of the survey) were chosen as a forms of conducting the survey. Among the questions in the questionnaire there was also one that focused on students' assessment of the strength of certain factors influencing forming of choice regarding a place for obtaining higher education. Basing on the results of the analysis of respondents' answers the importance of individual factors in the system of motives formation regarding the choice of the Institute of Higher Education for obtaining higher education were determined, namely: the territorial proximity of the Institute of Higher Education to the place of residence of the applicant - 19\%; place of positioning of the Institute of Higher Education in international University rankings $-26 \%$; the reputation of the Institute of Higher Education in the immediate environment of the applicant - 23\%; development of the infrastructure in Institute of Higher Education and the city which it is located in - 16\%; ; traditions of Institute of Higher Education in specialists training $-16 \%$ (the order of factors mentioning is identical to their placement in the text of the questionnaire). The held research revealed the fact that the problematics of quality of the educational activities of Institute of Higher Education and the higher education quality are not the defining ones in formation of preferences among applicants regarding the place of obtaining the quality of higher education.

Conclusions of the research. Such conclusions were formulated basing on the results of the held research.

1. The state can influence the applicant's choice of the place for obtaining of higher education, and, consequently, the level of popularity of that or another direction of future specialists training, through the mechanism of motivation of Institute of Higher Education to ensure compliance with the criteria of certain methodology for counting in international University rankings. The corresponding influence can be achieved by: establishing preferences and targeted funding for the highest-rated Institutes of Higher Education (focusing the state's efforts on developing the most competitive Institutes of Higher Education); clarification of the system of value orientations of representatives of society regarding the potentials of a particular Institute of Higher Education in formation of professional knowledge (influence on the applicant's social environment ); establishment of a dual form of training (will help to increase the level of financial independence of the student); optimization of the net of Institute of Higher Education (combining similar in profile Institutes of Higher Education within the structure of the most competitive Institutes of Higher Education) and the practice of using their main assets (organization of training in 
two shifts and getting rid of buildings with burdensome maintenance) etc.

2. Increasing the level of efficiency of the system ensuring the quality of educational activities and the higher education quality can be carried out with the help of its supplementing with a subsystem of public control (audit), because the sphere of higher education is the object not only of the state's attention, but also of society's. The basis for the formation of the model of public

\section{Постановка проблеми в} загальному вигляді та їі зв'язок із важливими науковими чи практичними завданнями.

Поступова інтернаціоналізація вищої освіти, як відповідь на глобалізаційні процесі у світі, обумовлює зміну структури та локації ринку освітніх послуг у сфері вищої освіти. Відкритість більшості країн світу до вільного переміщення ресурсів (капіталу, технологій, знань тощо), 3 одного боку, створює умови для соціально-економічного та суспільнополітичного розвитку окремих регіонів, а 3 іншого - сприяє загостренню конкуренції, у тому числі і на ринку освітніх послуг. Все далі частіше конкуренція між закладами вищої освіти (3ВО) переміщується у площину боротьби не лише за найбільш талановитих абітурієнтів, а за першокурсників взагалі. Сьогодні для багатьох $3 B О$ найбільш актуальним $\epsilon$ питання забезпечення набору першокурсників, адже від їхньої кількості зрештою залежить, як рівень фінансування закладу (оплата комунальних послуг; заробітна плата науковим та науково-педагогічним працівникам; фінансування навчальнометодичного забезпечення навчального процесу та науково-дослідних робіт тощо), так i рівень його престижу. Конкурування за абітурієнтів обумовлює необхідність пошуку адміністраціями ЗВО нових, нестандартних підходів до control over the educational activities quality of the Institute of Higher Education and the higher education quality can be based on the experience of the US and the $U K$ in ensuring the participation of nongovernmental organizations (self-governing public and professional organizations) in the process of implementation of the functions of quality management in sphere of higher education.

розбудови власної прийомної компанії. Традиційні механізми популяризації 3ВО серед абітурієнтів (наприклад “дні відкритих дверей”; інформаційні повідомлення старшокласників про можливості конкретного 3ВО; проведення майстер-класів та інших комунікативних заходів для випускників загальноосвітніх навчальних закладах; профорієнтаційна робота серед молоді тощо) сьогодні вже не забезпечують бажаного результату. Постійна зміна кон'юктури ринку освітніх послуг, так само як і тенденції до старіння населення, принаймні $\mathrm{y}$ більшості країн Європейського Союзу, вимагають від ЗВО більш глибокого розуміння, як особливостей формулювання мотивів абітурієнтів до вибору того чи іншого ЗВО та (або) спеціальності, так і змісту запитів роботодавців щодо якості трудового потенціалу майбутніх фахівців. Кожен 3 цих напрямів роботи, 3 огляду на складність та багатогранність прояву свого змісту, потребує на додаткову увагу як 3 боку суб'єктів управління організаційним розвитком університету, так і з боку вчених. Серед актуальних напрямів у розбудові наукових пошуків можуть бути i ті 3 них, змістовне спрямування яких зосереджено на з'ясуванні думки основних стейкхолдерів щодо питань якості вищої освіти, а також мотивів вибору абітурієнтами того чи іншого ЗВО у якості місця отримання обраної спеціальності. 
Відповідно до Стандартів i рекомендацій щодо забезпечення якості в Свропейському просторі вищої освіти студенти (здобувачі вищої освіти) розглядаються на рівні одного зі стейкхолдерів процесу забезпечення якості освітньої діяльності та якості вищої освіти [5, с. 9]. 3 огляду на цей факт можемо стверджувати про те, що з'ясування думки студентів щодо тих чи інших аспектів функціонування 3ВО є не лише можливим, а і необхідним кроком суб'єктів організаційного розвитку університетів у розбудові стратегії їхніх подальших прогресивних змін.

Аналіз останніх досліджень i публікацій, у яких започатковано розв'язання цієї проблеми i на які спирається автор. Теоретикометодологічну основу дослідження становлять результати наукових досліджень вітчизняних та зарубіжних вчених. Проблематика використання думки студентів щодо якості освітньої діяльності та якості вищої освіти досліджувалась В. Бабаєвим, С. Домбровською, С. Калашніковою, С. Квітом, Т. Лукіною, В. Морозом, Л. Паращенко, О. Романовським, В. Садковим та іншими вченими. Серед найбільш цікавих, відповідно до фокусу нашої безпосередньої уваги робіт, $\epsilon$ наукові доробки Бретаг Т., С. Махмуд, М. Воллес, Р. Волкер, У. МакГован, Дж. Іст, М. Грін, Л. Партриджа, К. Джеймса (Tracey Bretag, Saadia Mahmud, Margaret Wallace, Ruth Walker, Ursula McGowan, Julianne East, Margaret Green, Lee Partridge \& Colin James) - обгрунтовано потенціал методу опитування для з'ясування особливостей сприйняття студентами принципу академічної доброчесності [6], С. Буки, I. Буки (Stanislav Buka, Inta Buka) - визначено місце та роль методу опитування студентів у системі державного контролю за якістю надання освітніх послуг у сфері вищої освіти [3], Вільямса Дж., Д. Кейна, С. Сагу, Е. Сміт
(James Williams, David Kane, Satya Sagu \& Emily Smith) - порівняно результати опитування студентів перших та останніх курсів, а також визначено тенденції зміни думки студентів (зворотного зв'язку) залежно від використаних ЗВО практик [8], Р. Міколаджика, А. Максел, В. Найденовой, С. Меєр, В. Ансара (Rafael T. Mikolajczyk, Annette E. Maxwell, Vihra Naydenova, Sabine Meier \& Walid El Ansari) - визначено потенціали методу опитування студентів для 3'ясування їхнього психологічного стану під час навчання [9], С. Портера та П. Умбача (Stephen R. Porter \& Paul D. Umbach) обгрунтовано залежність вподобань вибору студентів під час опитування залежно від статусу їхнього університету (держаний або приватний), а також місця його розміщення та рівня матеріальнотехнічного забезпечення навчального процесу [11], Й. Ричардсона, Й. Слетера та Дж. Вільсон (John T. E. Richardson, John B. Slater \& Jane Wilson) - проведено аналіз результатів національного опитування студентів бакалаврських програм щодо якості освітньої діяльності 3ВО та рівня викладання освітніх програм [13], Я. Турелем (Yalın KılıçTürel) визначено ефективні методи проведення опитування та аналізу отриманих результатів [15], Дж. Ченг та X. Маршем (Jacqueline H.S. Cheng \& Herbert W. Marsh) - 3'ясовано напрями підвищення надійності та результативності проведення опитування студентів на загальнонаціональному рівні, а також обгрунтовано можливість порівняння отриманих результатів між окремими університетами [7] та інших дослідників. Проблематиці залучення студентів до процедур оцінювання результативності функціонування ЗВО були присвячені деякі наші 3 попередніх наукових публікацій $[1,2,10]$, тому у межах цієї публікації ми не будемо зупинятись на обгрунтуванні переваг та недоліків участі студентів у моніторингу освітньої 

МЕНЕДЖМЕНТ ТА АДМІНУСТРУВАННЯ

діяльності ЗВО на рівні самостійних експертів.

Виділення не вирішених раніше частин загальної проблеми, котрим присвячується дана стаття. Не зважаючи на достатній рівень дослідження проблематики залучення студентів до експертного оцінювання тих чи інших питань функціонування системи забезпечення якості освітньої діяльності та якості вищої освіти, окремі 3 напрямів відповідної за змістом наукової роботи все ще залишаються відкритими для подальших розробок. Наприклад, питання сприйняття якості вищої освіти студентами, зокрема через призму 3'ясування мотивів вибору ними місця отримання спеціальності (здобуття вищої освіти), не набули свого достатнього розвитку у межах оприлюднених наукових праць. Саме цей напрям в організації наукових досліджень було нами обрано у якості фокусу безпосередньої уваги.

Формулювання цілей статті (постановка завдання). Метою цього дослідження було обрано результати аналізу оцінки студентами потужності впливу окремих факторів на формування вибору ними місця здобуття вищої освіти.

3 огляду на предмет наукової уваги нами були обрані такі з наукових методів дослідження: метод аналізу та синтезу для визначення тих факторів, які здійснюють найбільший потужний за своєю силою вплив на формування мотивів абітурієнтів щодо вибору конкретного ЗВО як місця здобуття вищої освіти (за допомогою цього методу були відібрані для подальшого обговорення із студентами найбільш потужні за силою свого впливу фактори); метод експертного опитування у вигляді вибіркового інтерв'ю - для обмеження кола факторів лише тими 3 них, які, на думку студентів, є найбільш актуальними (за допомогою цього методу було відібрано лише п'ять найбільш значущих для студентів факторів); метод опитування у вигляді анкетування - для отримання первинної інформації від респондентів щодо предмету наукової уваги (за допомогою цього методу було сформовано достатній за своїм обсягом інформаційний ресурс); системноаналітичний метод - для аналізу змісту отриманих від студентів анкет (за допомогою цього методу було визначено значущість (оцінено рівень впливу) тих чи інших факторів на формування у майбутніх студентів мотивів вибору місця здобуття вищої освіти).

Виклад основного матеріалу дослідження 3 повним обгрунтуванням отриманих наукових результатів. Організація та проведення опитування студентів було передбачено планом виконання робіт у межах позагрантового проекту (проект не передбачав отримання його авторами та безпосередніми виконавцями програмних заходів будьяких ресурсів для проведення дослідження) "Оцінка якості вищої освіти”. Особливістю реалізації проекту стало залучення до участі у ньому ЗВО 3 країн, які мають принципово різне змістовно-культурологічне та суспільноісторичне підгрунтя для формування національних систем вищої освіти та відмінні соціально-економічні умови свого розвитку. У якості партнерів щодо реалізації завдань проекту на території обраних організаторами дослідження країн стали Балтійська Міжнародна Академія (м. Рига, Латвія) та Інститут міжнародної та порівняльної освіти Пекінського педагогічного університету (м. Пекін, Китай). Отже, участь у реалізації програмних заходів проекту взяли ЗВО з України, Латвії та Китаю. Залишаючи поза увагою обгрунтування наших вподобань щодо вибору ЗВОпартнерів саме 3 Латвії та Китаю (відповідний напрям наукової роботи нами було висвітлено у межах попередніх публікацій), так само як i аналіз 
отриманої від 3ВО-партнерів інформації (завдання проекту передбачали організацію анкетування студентів 3 України, Латвії та Китаю за змістом однієї та тієї самої анкети, а також обмін заповненими анкетами для подальшого самостійного аналізу кожним з учасників проекту), звернемо безпосередню увагу на окремі з отриманих результатів.

Вище ми звернули увагу на той факт, що у якості основного методу отримання інформації щодо предмету безпосередньої уваги авторами проекту було обрано метод опитування у вигляді вибіркового інтерв'ю (для уточнення змісту анкети та апробації розуміння іiі сутності потенційними респондентами) та анкетування (для формування інформаційноаналітичної бази дослідження). За результатами проведених із потенційними респондентами (студентами) інтерв'ю було визначено ті 3 основних напрямів проблематики забезпечення освітньої діяльності та якості вищої освіти, які, на їхню думку, є найбільш актуальними для оцінювання. Крім того, під час інтерв'ю було визначено найбільш зрозумілу для потенційних респондентів (студентів) форму розбудови майбутньої анкети. Для організації опитування студентів автором проекту «Оцінка якості вищої освіти» було опрацьовано відповідну анкету. Ї̈̈ зміст та структура були сформовані $з$ прийняттям до уваги методичних порад С. Садмана, Н. Бредберна та Н. Шварца щодо архітектоніки анкети [14]. У запропонованому до заповнення студентами вигляді анкета містила вісімнадцять питань, з яких три питання були спрямовані на з'ясування статево-вікових характеристик респондента, а також рівня його освіти. П'ятнадцять питань анкети були зосередженні на оцінюванні тих чи інших аспектів прояву проблематики якості вищої освіти. 3 огляду на обмеженість обсягів цієї публікації, а також з урахуванням факту висвітлення деяких із отриманих нами результатів у межах попередньо оприлю- днених наукових робіт, вважаємо за можливе зосередитись на аналізі відповідей респондентів лише за одним із фокусів уваги анкети, а саме за напрямом з'ясування думки українських студентів щодо впливу окремих факторів на вибір абітурієнтами місця здобуття вищої освіти. Відповідне до цього фокусу наукової уваги питання було сформульовано у вигляді пропозиції до респондента здійснити оцінювання рівнів впливу окремих 3 факторів на формування у нього мотиву вибору місця здобуття вищої освіти. На території України в опитуванні взяло участь 563 студенти віком від 18 до 35 років із Полтавської, Сумської, Харківської, а також підконтрольних Україні частин Донецької та Луганської областей, але не зважаючи на зусилля організаторів дослідження щодо розуміння змісту анкети респондентами, 21 з повернутих анкет виявились некоректно заповненими. Отже, нижче наведені результати були отримані за результатами аналізу 542 анкет. Враховуючи той факт, що опитування проводились лише на території Східної України, ми не можемо говорити про високий рівень репрезентативності отриманих результатів. Разом 3 тим, сформульовані нижче узагальнення можуть бути використані як суб'єктами публічного управління функціонуванням та розвитком системи вищої освіти, так і адміністраціями 3ВО, на рівні інформаційноаналітичного забезпечення процедур вступної компанії. Результати аналізу отриманих авторами дослідження відповідей щодо з'ясування потужності впливу окремих факторів на формування мотивів вибору місця отримання вищої освіти подано на рисунку 1.

За результатами аналізу отриманих результатів можемо сформулювати такі основні узагальнення.

По-перше, найбільш високим за рівнем свого впливу на формування у абітурієнтів мотиву вибору місця здобуття вищої освіти виявився фактор позиціону- 

МЕНЕДЖМЕНТ ТА АДМІНУСТРУВАННЯ

вання 3ВО у міжнародних університетських рейтингах. Респонденти оцінили вплив відповідного фактору на рівні $26 \%$. Такий результат став дещо неочікуваним для організаторів дослідження, адже під час вибіркового інтерв'ю $з$ потенційними респондентами у межах етапу уточнення змісту анкети та з'ясування рівня іiї розуміння студентами значущість цього фактору оцінювалась на достатньо низькому рівні.

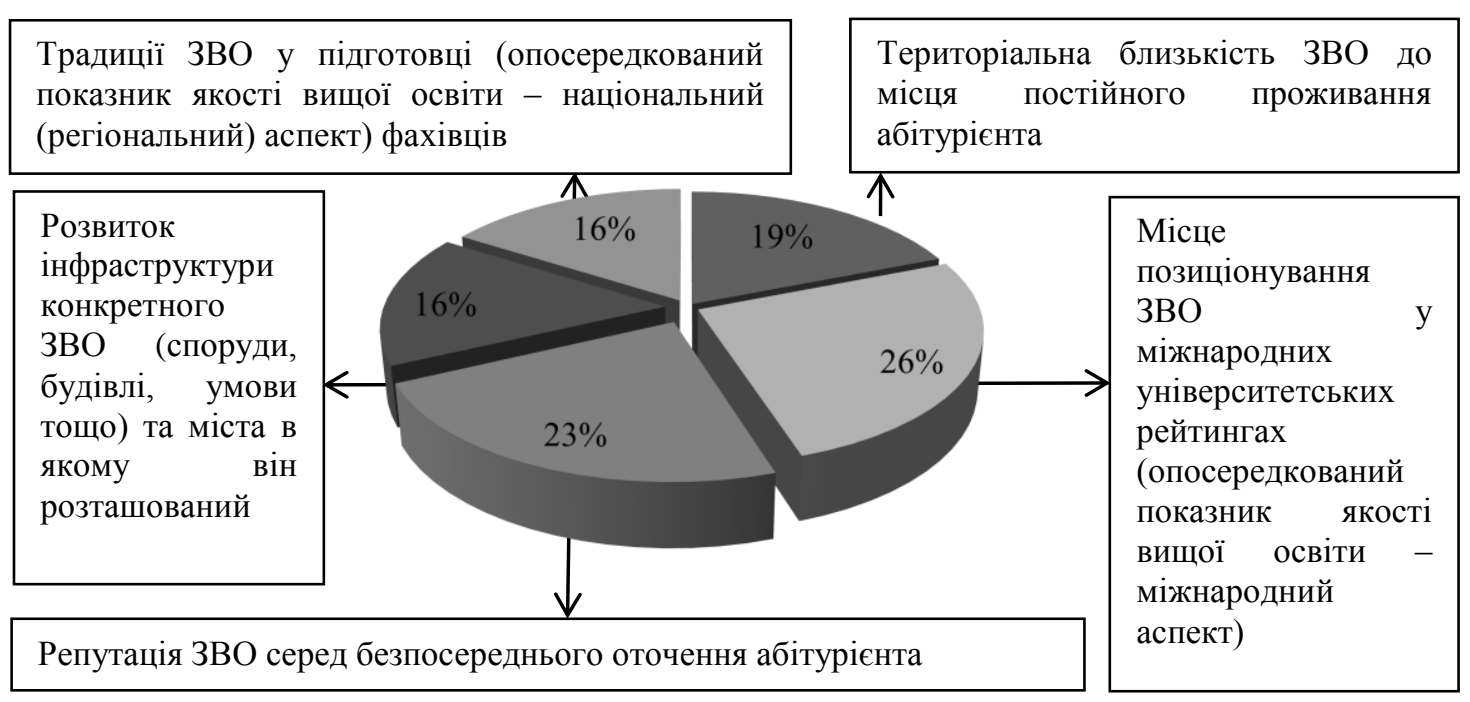

Рис. 1. Потужність впливу окремих факторів на вибір місия здобуття вищої освіти

Крім того, слід врахувати і той факт, що українські ЗВО представлені у межах міжнародних університетських рейтингів у незначній кількості, а отже оцінювання рівня їхнього позиціонування обмежується лише декількома провідними 3ВО. Наприклад, у визнаний на світовому рівні рейтинг World University Rankings від британської консалтингової компанії Quacquarelli Symonds (QS) у 2020 році було включено лише 6 українських ЗВО (для порівняння: у 2019 - 6 3ВО; у 2018 - 6 3ВО) [12]. Виникає ситуація, за якою дія фактору «місце позиціонування ЗВО у міжнародних університетських рейтингах» щодо українських $3 \mathrm{BO}$ обмежується лише шістьма університетами, що суттєво впливає на якість оцінювання респондентами значущості відповідного фактору.

По-друге, достатньо значущим за силою свого впливу виявився фактор репутації ЗВО серед безпосереднього оточення абітурієнта. Респонденти оцінили вплив відповідного фактору на рівні 23\%. Іншими словами, на вибір абітурієнтом місця здобуття вищої освіти суттєво впливає думка тих осіб, з якими постійно контактує майбутній студент (члени родини, друзі, однолітки тощо). Достатньо високий рівень впливу цього фактору може бути пояснений через призму соціальної сутності людини. Свого часу К. Маркс обгрунтував залежність індивідуальної свідомості від суспільного буття (залежність надбудови, у нашому випадку - вподобання щодо вибору ЗВО, від базису, у нашому випадку - соціального оточення абітурієнта). Пізніше ця теза набула свого розвитку у роботах К. Манхейма який довів обумовленість знання (у нашому випадку вибору, адже виважений вибір здійснюється передусім на підставі знань про предмет вибору та його 
альтернативи) соціальними, культурними, класовими зв'язками його носія. Іншими словами, вибір абітурієнта щодо місця здобуття вищої освіти $є$ соціально обумовленим та таким, який більше відповідає думці соціальних об'єктів безпосередньої взаємодії абітурієнта, ніж його власним поглядам.

По-третє, достатньо відчутним за рівнем своєї значушості залишається вплив фактору територіальної близькості ЗВО до місця постійного проживання абітурієнта. Значущість цього фактору була оцінена на рівні 19\%. Такий результат не став несподіваним для авторів проекту “Оцінка якості вищої освіти”, адже у переважній своїй більшості абітурієнти не готові до переїзду до іншого регіону для здобуття вищої освіти. На нашу думку, така значущість фактору може бути пояснена через призму: суспільно-політичного напруження в країні (антагоністичність поглядів мешканців із різних регіонів на зміст системи ціннісних оріснтацій); недостатнього економічного потенціалу для забезпечення навчання за межами регіону (фінансові витрати родини на гідне забезпечення умов життєдіяльності студента за межами регіону постійного проживання, як правило, є вищими за умови їх порівняння 3 відповідними витратами на утримання студента, який навчається у межах регіону постійного місця проживання); психологічна неготовність переважної більшості випускників до проживання за межами звичного соціального оточення) тощо. В основу природи формування значущості цього фактору, на відміну від всіх інших відібраних для оцінювання (рисунок 1), не було покладено проявів феномену якості вищої освіти. Отже, фактор, який не має зв'язків 3 проблематикою якості освітньої діяльності та якості вищої освіти достатньо суттєво впливає на формування у абітурієнтів мотиву вибору місця здобуття вищої освіти.
По-четверте, найменшим за своїм значенням, серед запропонованих до оцінювання факторів впливу на формування мотиву вибору абітурієнтом місця здобуття вищої освіти, на думку студентів, є фактори розвитку інфраструктури конкретного ЗВО (16\%) та його традиції у підготовці майбутніх фахівців (16\%). Ці фактори можуть бути віднесені до опосередкованих показників якості вищої освіти, але при цьому вони не $\epsilon$ другорядними, адже сам факт включення їх до анкети на рівні варіантів вибору (вище було звернуто увагу, що всі питання, так само як і варіанти відповіді на них, були узгоджені 3 потенційними респондентами під час проведення вибіркових інтерв'ю) свідчить про їхню значущість. Разом з тим, факт відносно невеликої за рівнем значущості факторів розвитку інфраструктури ЗВО та його традиції у підготовці фахівців свідчить про існування певних суперечностей, а саме: фактор розвитку інфраструктури конкретного ЗВО (16\% - один із найнижчих за значенням показників) має причинно-наслідковий зв'язок із фактором місця позиціонування ЗВО в міжнародних університетських рейтингах (26\% - найбільший за своїм значенням показник); фактор традицій у підготовці майбутніх фахівців $(16 \%$ - один із найнижчих за значенням показників) має причинно-наслідковий зв'язок із фактором репутації ЗВО серед безпосереднього оточення абітурієнта ( $23 \%$ - один із найбільших за значенням показників). 3 огляду на ці протиріччя можемо припустити можливість комплексного сприйняття тих факторів, які обумовлюють один одного.

По-п'яте, серед запропонованих авторами проекту до експертного оцінювання студентами факторів впливу на формування у абітурієнтів мотиву вибору місця здобуття вищої освіти були у тому числі й ті з них, які мають зв'язок із проблематикою якості вищої освіти, а 
саме: місце позиціонування ЗВО в міжнародних університетських рейтингах (опосередкований показник якості вищої освіти - міжнародний аспект); традиції ЗВО у підготовці фахівців (опосередкований показник якості вищої освіти - національний (регіональний) аспект). Безумовно, інші фактори (репутація ЗВО серед безпосереднього оточення абітуріснта; розвиток інфраструктури 3ВО) також можуть бути розглянуті через призму їх кореляції 3 проблематикою якості вищої освіти, але на нашу думку, така залежність $\epsilon$ достатньо умовною. Залишаючи дискусію навколо питання обгрунтування зв'язків того чи іншого фактору $з$ проблематикою якості вищої освіти осторонь (цілком очевидно, що таке обгрунтування потребує окремого напряму наукового пошуку), звернемо увагу на потужність прояву тих факторів, зв'язок змісту та природи виникнення яких 3 відповідною проблематикою не підлягає сумнівам (вище ми визначили такі фактори). Сумарний рівень фактору місця позиціонування ЗВО у міжнародних університетських рейтингах та фактору традицій у підготовці фахівців дорівнює $42 \%$. Такий показник $\epsilon$ достатньо відчутним за своїм впливом на мотив формування вподобань абітурієнта щодо місця здобуття вищої освіти, але не $\epsilon$ визначальним.

Висновки 3 даного дослідження та перспективи подальших розвідок у даному напрямку. Враховуючи вище наведене можемо сформулювати такі основні висновки.

1. Держава може впливати на вибір абітурієнтами місць здобуття вищої освіти, а відповідно, i на рівень популярності того чи іншого напряму підготовки майбутніх фахівців (як правило переважна більшість ЗВО має певну спеціалізацію щодо підготовки фахівців), через механізм заохочення (спонукання) ЗВО до забезпечення відповідності критеріям визначених методологією обрахування міжнародних університетських рейтингів. Відповідний механізм може бути використаний через інструментарій встановлення преференцій та адресного фінансування. На нашу думку, найбільш ефективне використання потенціалів цих інструментів може бути здійснено у межах державної програми підтримки найбільш рейтингових ЗВО (наприклад, за результатами національного академічного рейтингу 3ВО) у їхньому прагненні підвищити рівень свого позиціонування на міжнародному ринку освітніх послуг. У якості прикладу функціонування відповідної програми на державному рівні можуть бути розглянуті урядові проекти Китаю 211 (відібрано найбільш важливі для розвитку економіки Китаю ЗВО та визначено вектори i джерела їхнього розвитку для підвищення рівня глобальної конкурентоспроможності) та 985 (затверджено ЗВО 3 пріоритетною чергою та рівнем фінансування), а також державної програми 863 (державна програма 3 розвитку так званих високих технологій, у межах плану реалізації якої 3ВО відведена неабияка роль).

2. Вплив на вибір абітурієнтом місця здобуття вищої освіти (корегування вибору) може бути здійснений через уточнення системи ціннісних орієнтацій тих чи інших представників соціуму щодо потенціалів конкретного ЗВО у формуванні фахових знань та забезпеченні розвитку трудових можливостей майбутнього фахівця. Використання адміністраціями ЗВО інструменту впливу на безпосереднє оточення абітурієнтів може бути використане у межах процедур популяризації ЗВО та забезпечення вступної компанії. Особливість використання цього інструменту полягає у тому, що об'єктом уваги стає не безпосередньо сам абітурієнт, а його оточення. На державному рівні 
відповідний інструментарій може бути використаний у межах механізмів формування державного замовлення на підготовку фахівців 3 вищою освітою та проведення профорієнтаційної роботи серед молоді. Завдяки цьому інструменту суб'єкти публічного управління мають опосередковану можливість впливу не лише безпосередньо на ринок освітніх послуг (популяризація тих чи інших спеціальностей та (або) 3ВО), а і на ринок праці. Разом з тим, слід розуміти, що потенціали використання суб'єктом управління інструментарію впливу на оточення абітурієнта 3 метою зміни його вподобань щодо місця здобуття вищої освіти залежать як від рівня концептуальної зрілості майбутнього студента (випускники загальноосвітніх навчальних закладів, 3 огляду на відсутність життєвого досвіду, є більш схильними до сприйняття порад від представників соціального оточення), так i від його психофізіологічних особливостей (схильність до сприйняття порад; впевненість в собі; здатність до результативної соціальної взаємодії тощо).

3. 3 метою мінімізації впливу фактору, природа виникнення якого не пов'язана 3 якістю вищої освіти, а саме фактору територіальної близькості ЗВО до місця постійного проживання абітурієнта, пропонуємо розглянути можливість використання потенціалів дуальної форми навчання у ЗВО та підвищення рівня психологічної готовності випускників загальноосвітніх навчальних закладів до самостійного життя. Запровадження дуальної форми навчання дозволить не лише узгодити взаємодію освітньої та виробничої сфер із підготовки майбутніх фахівців, a i сприятиме формуванню умов для підвищення рівня фінансової незалежності студента від родини, що його утримує. Студент, навчаючись у сфері реального сектору економіки, матиме можливість здобувати не лише практично значущі професійні знання, а i отримувати грошову винагороду за результатами їх використання. Підвищення рівня психологічної підготовки учнівської молоді, наприклад, 3 акцентом уваги на вихованні самостійності та відповідальності, сприятиме, з одного боку, підвищенню адаптивної здатності особистості до дії у нових соціальних умовах, а 3 іншого підвищенню рівня трудового потенціалу майбутніх фахівців, передусім за рахунок розвитку їхніх якісних характеристик.

4. Вплив суб'єктів публічного управління на забезпечення якості освітньої діяльності та якості вищої освіти може бути здійснений через створення умов для розвитку інфраструктури ЗВО та його традицій. В умовах недостатнього фінансування професійної діяльності державних ЗВО відповідний напрям може бути реалізований через механізм об'єднання схожих за своїм профілем ЗВО. Таке об'єднання може бути здійснено за принципом - менш ефективні ЗВО входять до структури більш ефективних ЗВО з подальшою оптимізацією останніх. Такий крок держави дозволить, з одного боку, уникнути соціальної напруженості під час реорганізації (студенти та науково-педагогічні працівники менш престижного 3ВО отримують відповідний статус у межах більш престижного ЗВО), а 3 іншого - сприятиме скороченню кількості ЗВО. Крім того, у якості одного 3 інструментів розвитку інфраструктури ЗВО може бути крок держави щодо створення умов, за яких ЗВО будуть змушені переглянути задіяні у навчальному процесі основні фонди (будівлі, споруди, земельні ділянки, устаткування тощо) за напрямом їх скорочення. Більшість 3 діючих на цей час ЗВО не використовуе у повному обсязі наявні у їхньому розпорядженні основні фонди, але при цьому забезпечує 
їхне утримання (комунальні платежі, охорона тощо). Перегляд задіяних у навчальному процесі основних фондів за напрямом їхнього скорочення дозволить ЗВО скоротити витрати на їхнє утримання та спрямувати вивільнені ресурси на розвиток тих об'єктів, які залишаться під управлінням 3ВО. За цим напрямом роботи адміністрації ЗВО також можуть розглянути можливість підвищення рівня ефективності використання основних фондів, наприклад за рахунок запровадження навчання у дві зміни.

5. Проблематика забезпечення якості вищої освіти не відіграє визначального впливу на вибір абітурієнтом місця здобуття вищої освіти. Цей факт став можливим внаслідок відсутності традицій у функціонуванні системи забезпечення якості освітньої діяльності та якості вищої освіти як на університетському, так і на державному рівнях. 3 одного боку, Закон України "Про вищу освіту" закріплює норми щодо системи забезпечення якості вищої освіти в Україні (підсистема внутрішнього забезпечення якості освітньої діяльності та якості вищої освіти; підсистема зовнішнього забезпечення якості освітньої діяльності ЗВО та якості вищої освіти; підсистема забезпечення якості діяльності Національного агентства із забезпечення якості вищої освіти і незалежних установ оцінювання та забезпечення якості вищої освіти [4]), але ці норми не мають достатніх традицій у

\section{Список літератури:}

1. Мороз С. А. Державне управління розвитком трудового потенціалу ВНЗ: компетенція людини, університету та держави [електронний ресурс] / C. А. Мороз // Державне управління: удосконалення та розвиток: електронне наукове фахове видання Академії муніципального управління. - своїй реалізації. Пропонуємо доповнити систему забезпечення якості вищої освіти в Україні підсистемою громадського контролю (аудиту), адже сфера вищої освіти є об'єктом уваги не лише держави, а і суспільства. В основу формування моделі громадського контролю за якістю освітньої діяльності ЗВО та якістю вищої освіти може бути покладений досвід США та Великобританії щодо забезпечення участі недержавних організацій (самоврядних громадських та професійних організацій) в реалізації функцій управління якістю у сфері вищої освіти.

Вище наведені висновки не вичерпують проблематики впливу окремих факторів на вибір абітурієнтами місця здобуття вищої освіти, а лише сприяють розвитку інформаційного підгрунтя для подальшого обговорення порушених питань. Серед найбільш перспективних напрямів щодо організації подальших наукових пошуків $є$ ті 3 них, фокус наукової уваги яких зосереджено на порівнянні відповідей українських студентів із відповідями студентів 3 інших залучених до проекту “Оцінка якості вищої освіти” країн. Важливим та практично значущим в контексті проблематики забезпечення якості освітньої діяльності та якості вищої освіти $\epsilon$ напрям, предметом наукової уваги якого $є$ думка роботодавців щодо якості підготовки фахівців 3 вищою освітою.

№4. - 2016. - Режим доступу: http://www.dy.nayka.com.ua/?op=1\&z=967

$$
\text { 2. Мороз С. А., Мороз В. М. }
$$

Підвищення якості трудового потенціалу вітчизняних ВНЗ в контексті змісту механізмів міжнародної співпраці / С. А. Мороз, В. М. Мороз // Проблеми та перспективи формування національної гуманітарно-технічної еліти: зб. наук. праць 
НТУ “ХПІ”. - Вип. 43 (47). - 2015. - С. 100 $-112$

3. Мороз С. А., Бука I. С., Бука С. А., Мороз В. М. Оцінювання якості вищої освіти студентами як елемент системи державного контролю за якістю надання освітніх послуг закладами вищої освіти (на прикладі опитування студентів Балтійської Міжнародної Академії, Латвія) / С. А. Мороз, І. С. Бука, С. А. Бука, В. М. Мороз // Вісник НУЦЗУ. Серія “Державне управління". - Вип. 2 (9). - 2018. - С. $282-295$

4. Про вищу освіту / Закон України від 01.07.2014 № 1556-VII // Офіційний вісник України. - № 63. - 2014. - С. 7 14

5. Стандарти і рекомендації щодо забезпечення якості в Європейському просторі вищої освіти (ESG). "Свропейська асоціація забезпечення якості вищої освіти”. - К.: ТОВ “ЦС”. 2015. - C. 32

6. Bretag, T., Mahmud S., Wallace, M. (2014), "Teach us how to do it properly!" An Australian academic integrity student survey, Studies in Higher Education, vol. 39, iss. 7, pp. $1150-1169$

7. Cheng, J.H., Marsh, H.W. (2010), "National Student Survey: are differences between universities and courses reliable and meaningful?", Oxford Review of Education, vol. 36, iss. 6. pp. $693-712$

8. Williams, J., Kane, D., Sagu, S., Smith, E. (2008), "Exploring the national student survey: Assessment and feedback issues", York: The Higher Education Academy Innovation Way, p. 84

9. Mikolajczyk, R. T., Maxwell, A. E., Naydenova, V., Meier, S. (2008), "Depressive symptoms and perceived burdens related to being a student: Survey in three European countries", Clinical Practice and Epidemiology in Mental Health, no. 19, available at: https://cpementalhealth.biomedcentral.com/a rticles/10.1186/1745-0179-4-19
10. Moroz, S. (2017), "Public administration of the quality of higher education in the context of the norms of international quality standards: principle of orientation towards the customer", Juvenis scientia, no. 10 , pp. $13-16$

11. Porter, S. R., Umbach, P. D. (2006), "Student Survey Response Rates across Institutions: Why Do they Vary?", Research in Higher Education, no. 47, pp. $229-247$

12. QS World University Rankings (2020), "Topuniversities: Rankings. Quacquarelli Symonds", available at: https://www.topuniversities.com/universityrankings/world-university-rankings/2020

13. Richardson, J.T., Slater, J.B., Wilson, J (2007), "The National Student Survey: development, findings and implications", Studies in Higher Education, vol. 32 , iss. 5 , pp. $557-580$

14. Sudman, S., Bradburn, N., Schwarz, N. (2010), "Thinking About Answers: The Application of Cognitive Processes to Survey Methodology", San Francisco: Jossey-Bass, p. 322

15. Türel, Y.K. (2011), “An interactive whiteboard student survey: Development, validity and reliability", "Computers \& Education", vol. 57, iss. 4, pp. $2441-2450$

\section{Reference:}

1. Moroz, S. A. (2016), "Public administration of the development of the university's labor potential: the competence of the person, the university and the state", Derzhavne upravlinnia: udoskonalennia ta rozvytok: elektronne naukove fakhove vydannia Akademii munitsypalnoho upravlinnia, no. 4, available at: http://www.dy.nayka.com.ua/?op=1\&z=967

2. Moroz, S. A., Moroz, V. M. (2015), "Improving the quality of labor potential of domestic universities in the context of the content of mechanisms of international cooperation", Problemy ta perspektyvy formuvannia natsionalnoi 
humanitarno-tekhnichnoi elity: zb. nauk. prats NTU "KhPI", vol. 43 (47), pp. $100-$ 112

3. Moroz, S. A., Buka, I. S., Buka, S. A. and Moroz, V. M. (2018), "Evaluation of the quality of higher education by students as an element of the system of state control over the quality of provision of educational services to higher education institutions (on the example of a survey of students of the Baltic International Academy, Latvia)", Visnyk NUTsZU, Seriia "Derzhavne upravlinnia" 2 (9), pp. $282-295$

4. "About higher education" (2014), Law of Ukraine dated 01.07.2014 No. 1556VII, Ofitsijnyj visnyk Ukrainy, no. 63, pp. 7 $-14$

5. "Standards and Recommendations for Quality Assurance in the European Higher Education Area (ESG): The European Association for Quality Assurance in Higher Education", (2015), K.: TOV "TsS"

6. Bretag, T., Mahmud S., Wallace, M. (2014), "Teach us how to do it properly!" An Australian academic integrity student survey, Studies in Higher Education, vol. 39, iss. 7, pp. $1150-1169$

7. Cheng, J.H., Marsh, H.W. (2010), "National Student Survey: are differences between universities and courses reliable and meaningful?", Oxford Review of Education, vol. 36, iss. 6. pp. $693-712$

8. Williams, J., Kane, D., Sagu, S., Smith, E. (2008), "Exploring the national student survey: Assessment and feedback issues", York: The Higher Education Academy Innovation Way, p. 84

9. Mikolajczyk, R. T., Maxwell, A.

E., Naydenova, V., Meier, S. (2008),

Стаття надійшла до редколегї 13.03.2020
"Depressive symptoms and perceived burdens related to being a student: Survey in three European countries", Clinical Practice and Epidemiology in Mental Health, no. 19, available at: https://cpementalhealth.biomedcentral.com/a rticles/10.1186/1745-0179-4-19

10. Moroz, S. (2017), "Public administration of the quality of higher education in the context of the norms of international quality standards: principle of orientation towards the customer", Juvenis scientia, no. 10 , pp. $13-16$

11. Porter, S. R., Umbach, P. D. (2006), "Student Survey Response Rates across Institutions: Why Do they Vary?", Research in Higher Education, no. 47, pp. $229-247$

12. QS World University Rankings (2020), "Topuniversities: Rankings. Quacquarelli Symonds", available at: https://www.topuniversities.com/universityrankings/world-university-rankings/2020

13. Richardson, J.T., Slater, J.B., Wilson, J (2007), "The National Student Survey: development, findings and implications", Studies in Higher Education, vol. 32 , iss. 5 , pp. $557-580$

14. Sudman, S., Bradburn, N., Schwarz, N. (2010), "Thinking About Answers: The Application of Cognitive Processes to Survey Methodology", San Francisco: Jossey-Bass, p. 322

15. Türel, Y.K. (2011), “An interactive whiteboard student survey: Development, validity and reliability", "Computers \& Education", vol. 57, iss. 4, pp. $2441-2450$ 